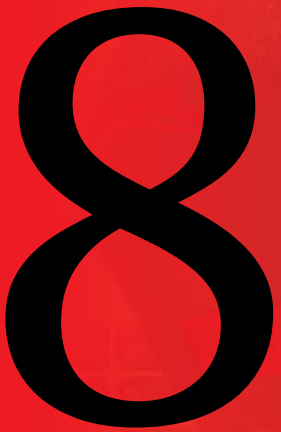

\title{
MAKING THE WORLD SAFE (FOR CHINA)
}

\section{Gerry Groot}




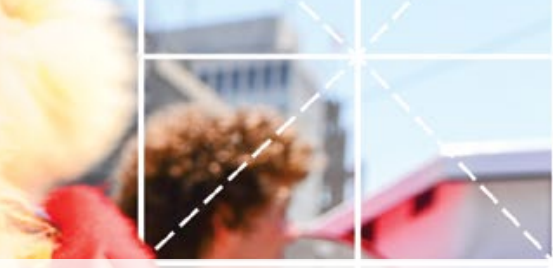

THE YEAR 2016 WAS notable for the visibility of China's international ascendance: in addition to military and diplomatic assertiveness in the South China Seas, it invested billions of dollars in Hollywood's film industry, foreign-based media, academic, and financial institutions such as the Asian Infrastructure Investment Bank. Despite international concerns about Chinese government kidnappings of dissidents abroad, meanwhile, for the first time a Chinese official has been elected head of Interpol.
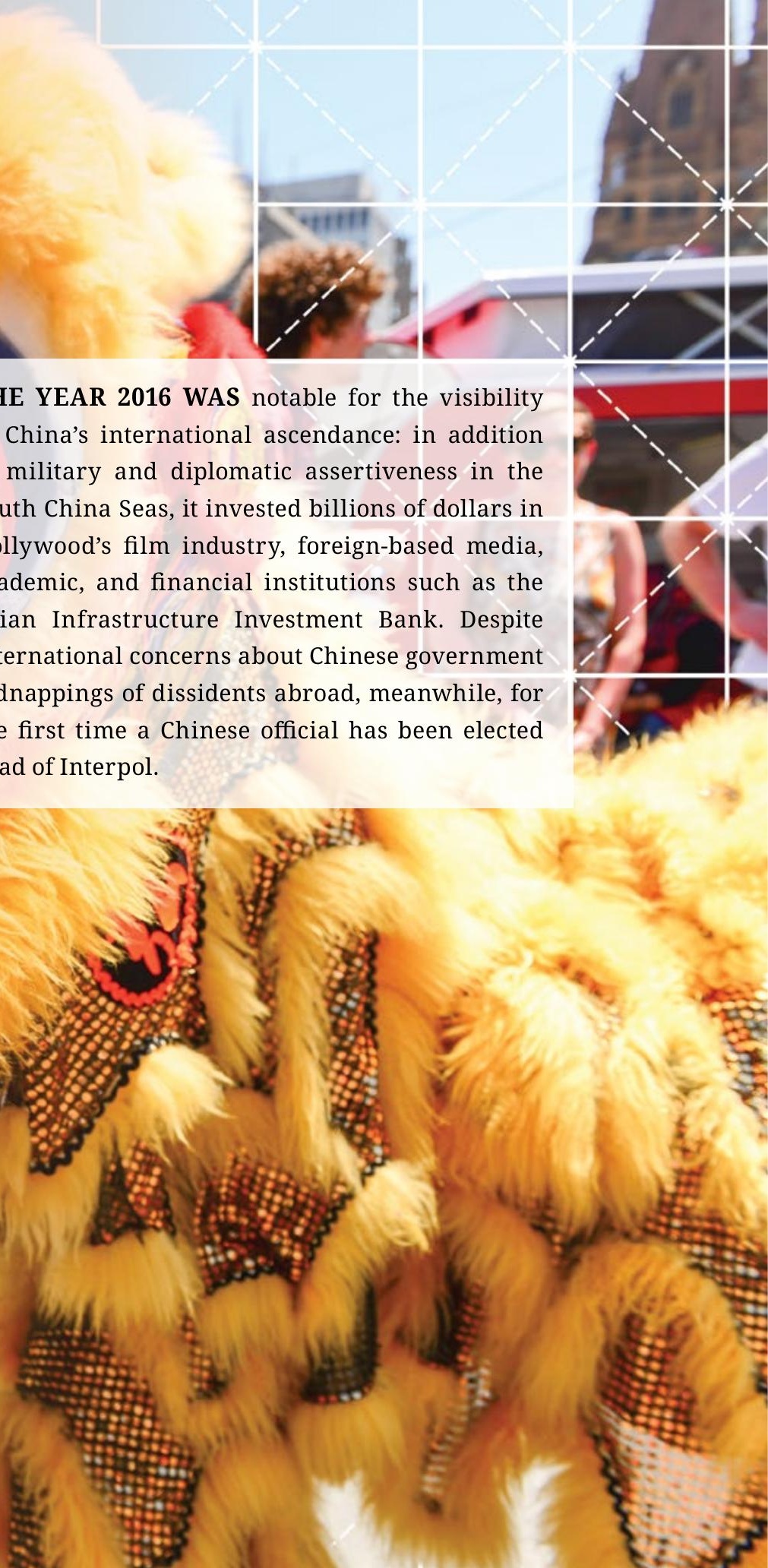
The government of Xi Jinping has worked boldly to create an international environment conducive to the Party achieving its goals. Its strategy includes both direct intervention and 'soft power' initiatives. The Chinese Party-state system can harness commercial deals, and carry out propaganda

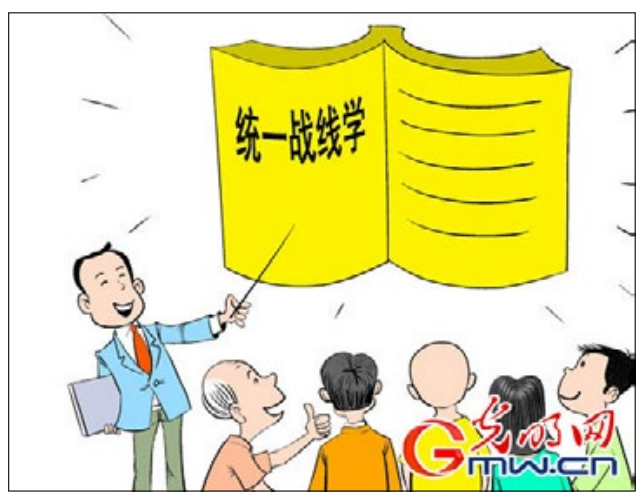

Learning about the United Front Source: img.gmw.cn and United Front Work 统一战线工作 (see the China Story Yearbook 2014: Shared Destiny, Forum 'The United Front in an Age of Shared Destiny', pp.129-134) in relatively systematic and long-term ways impossible for democracies to emulate.

If we exclude China's military and diplomatic activities, which are discussed elsewhere (see Chapter 9 'Strategic Control', pp.316-331, and Information Window 'Taiwan and the South China Sea', pp.332-333), the Chinese Communist Party's (CCP) main aim is to foster positive attitudes or understanding of Chinese positions in international media, institutions, and general publics. It also wishes to reshape these media and institutions so that they better reflect China's official values and serve its interests. The Party-state is also continuing to expand its links with overseas Chinese groups, from long-established communities to new emigrants. The aims are to build or reinforce identification with China, allow monitoring, isolate dissidents, and influence local politics.

Underlying China's outreach is a strong desire for redress, if not vengeance, for past national humiliations, and a desire for an international 'voice' befitting a nation that now boasts the world's second largest economy (see the China Story Yearbook 2015: Pollution, Forum 'One Belt One Road: International Development Finance with Chinese Characteristics', pp.245-250). It wants recognition of its long history and rich culture, and an end to the global dominance of the English language and 'Western' 




I 'United Front' (the joined hands), 'Party leadership' (centre) Source: img.gmw.cn or 'universal' values (see the China Story Yearbook 2013: Civilising China, Conclusion 'A Clash of Civilisations', pp.426-433). As Xi declared in 2014, 'the stories of China should be well told, voices of China wellspread and characteristics of China well explained'.

The Party-state is keen to see a dramatic change

in international perceptions of China as reflected, for example, in opinion polls carried out by the US-based 'non-partisan fact tank', the Pew Research Center. Respondents give China credit for its growing economy. But overall, median approval among the respondents in surveyed countries in 2015 was only about fifty-five percent - although the figure is higher among young people generally and especially in Africa and Latin America. Among neighbouring countries, issues such as human rights and pollution, border tensions, and other factors take the numbers lower: only nine percent of Japanese and nineteen percent of Vietnamese view China favourably compared to thirty-eight percent of Americans and fifty-seven percent of Australians. In Pakistan, however, approval registers at eightytwo percent. ${ }^{1}$ As a very rough measurement of soft power influence, these numbers are a poor result for expensive attempts at image management. But it is still early days.

\section{Buying Hollywood}

Since 2006, Beijing has encouraged its cultural industries, including through strategic investment, to compete with those of Japan and the US. International success with films, animation, literature, and television has generally proven elusive, with some exceptions (see Chapter 5 'Culture: In and Out of Control', pp.148-164). But these exceptions are unlikely to be- 
come 'main melody' 主旋律 productions - as those are explicitly created to sing the Party's tune. The new 2016 film law is increasing the degree to which the Party will control and guide Chinese cinema (see Chapter 5 'Culture: In and Out of Control', p.153). But never mind trying to cultivate audiences overseas,

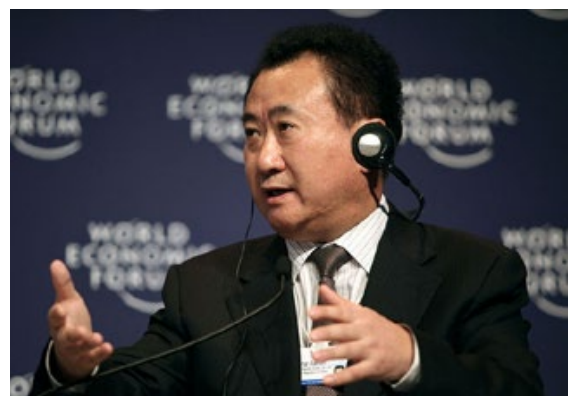

Wang Jianlin

Image: Wikimedia Commons Chinese domestic films have enough trouble competing with foreign ones for the box office at home, despite protectionist policies that allow only thirty-four foreign films to screen in China per year.

If you can't beat them, buy them. In 2016, real estate billionaire Wang Jianlin 王健林, of Dalian Wanda 大连万达 shopping centre fame, spent billions on AMC, the world's largest theatre chain. In July, he used AMC first to buy Europe's largest cinema chain, Odeon \& UCI Cinemas Group, and then the Carmike chain (to total more than 636 US cinemas, fifty in Australia, and 187 in China). On the production side, in January, Wanda bought the Hollywood production and finance company Legendary Entertainment (which co-produces films with both Warner Bros and Universal Studios) and then swooped up Dick Clark Studios in November as well. According to Business Insider, Wang eventually wants to own one of Hollywood's big six studios, while Bloomberg has written of Wang's determination to control twenty percent of the world's film market by $2020 .^{2} \mathrm{His}$ goal, as he told a Chinese TV interviewer in August, is to 'change the world where the rules are set by foreigners'. ${ }^{3}$

Other Chinese corporate players getting involved in Hollywood include Alibaba 阿里巴巴集团, Tencent 腾讯, and even Hunan TV, which signed a US\$1.5 billion co-financing and co-production pact with Lionsgate, America's largest 'mini-major' film studio. Co-productions are one way of getting around the quota system. They feature more roles for Chinese actors, and pay 
attention from the start of the process to official Chinese sensitivities and to storylines that appeal to both Chinese audiences and censors. The beauty of co-productions from the Chinese perspective, stated Propaganda Chief, Liu Qibao 刘奇葆, in Guangming ribao 光敏日报 in 2014, is that Chinese propaganda is much more palatable when it is seen as imported from abroad. ${ }^{4}$ Another incidental benefit is that co-productions can help the Chinese partners 'skill up'.

Even on its own, Hollywood is working hard to make films for the Chinese market, which is now often crucial at the box office. When MGM was doing post-production for its 2012 film Red Dawn, it changed the villains from Chinese to North Korean. The 2014 Wikileaks dump of Sony Corporation emails exposed, among other things, how Sony modified movies such as Pixels to maximise their attractiveness to Chinese audiences and censors. Hollywood films today increasingly include Chinese actors and products, and endeavour to portray China in a positive light. In the 2015 film The Martian, Chinese space technicians help out an American stranded on Mars. Independence Day: Resurgence (2016), meanwhile, features Angelababy (杨颖) - a Shanghai-born actress and reality TV celebrity. Some films that did poorly in the West have done well enough in China for a sequel to be produced (World of Warcraft, for example).

The darker side of this is the fear that studios will pander to Chinese sensibilities at the expense of artistic integrity or free expression. In the case of Marvel's Dr Strange (2016), concern over China's reaction to the casting of a Tibetan in the key role of the Ancient One (a Tibetan in the original comic) led to the character being changed to a Scottish witch (played by Tilda Swinton). ${ }^{5}$

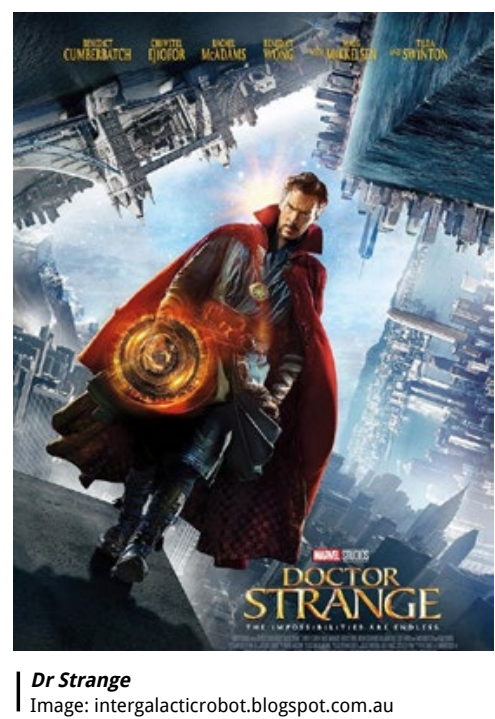



Case of Monkey Magic

There is also the small irony that a television series, Monkey or Monkey Magic (NTV, 1979-1980) achieved considerable success internationally in the early 1980s, particularly in Australia and Britain, and was popular for a further two decades or more. It even became a successful play. But not only was Monkey a Japanese production, it was also

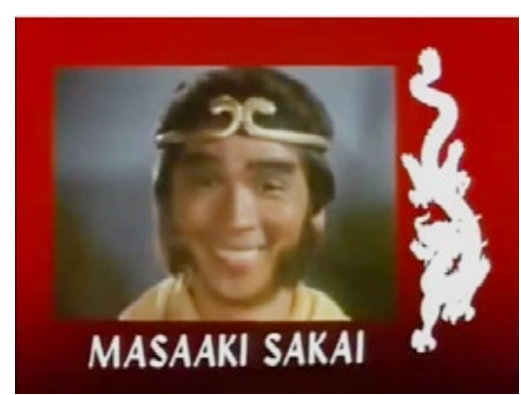

Still from Monkey Magic: Masaaki Sakai played the role of Monkey Image: YouTube notable for using irreverent and sly humour quite at odds with Chinese injunctions about dignity and the need to be didactic and exemplary. Many related Japanese anime series such as Dragon Ball (1984-1995) have had even greater international success, with any acclaim or affection going to Japan, despite the Chinese roots of the original stories. In contrast, not one of the many Chinese versions have had international success. Even if they ever do, the experience of Japan suggests that this is unlikely to translate into the soft power that China's leaders desire.

\section{Extending Online Censorship Beyond the Great Firewall}

Facebook has been banned in China since the Urumqi (Xinjiang) riots in 2009. That Mark Zuckerberg has since been learning Chinese and holding high-level meetings in China, including with Xi Jinping, is old news. In November 2016, The New York Times revealed that Facebook has been working on censorship software tools that might help it regain access to the world's biggest social media market. These would allow the suppression 
of posts from appearing in people's feeds in certain geographic areas. This is understandably controversial, for both the moral issues involved and the fear that Chinese government access to Facebook users' data could compro-

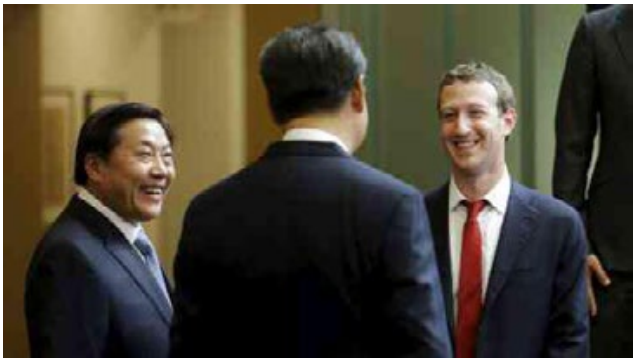

Mark Zuckerberg meets with Xi Jinping and Lu Wei Image: Mark Zuckerberg, Facebook mise the safety, violate the privacy, and interfere with the freedoms of people outside China as well. Facebook already blocks content (55,000 items in total over six months in 2015) in countries including Pakistan, Russia, and Turkey to comply with those countries' censorship regimes. But this software would take it to another level. ${ }^{6}$ On 6 December, Facebook suddenly deleted the account of the overseas-based, Chinese-language Boxun 博讯 news service, which publishes articles on human rights abuses in China, among other topics.

China's own social media, including Tencent's WeChat 微信, blocks some websites (such as gambling ones) for its more than 846 million users in China, while allowing access to 70 million people outside China. There is also censorship of sensitive issues such as Falun Gong, but it is usually so subtle that users don't notice. Tencent has to allow state access to its accounts in order to function. It's a Chinese company. But if Facebook does the same, or even similar, as the title of an article published in December in the online news magazine Quartz put it: 'There's only one clear winner if Facebook breaks into China - and it's not Facebook'.?

The Chinese Party-state has big ambitions for extending its control in the online world generally. In March 2016, the US handed control of the Internet to the Internet Corporation for Assigned Names and Numbers, responsible for domain names, which was originally a creation of the US Department of Commerce, and its headquarters are still in the US. But it is now entirely independent, with members that include governments, 
corporations, and individuals from around the world. The final transition was a source of anxiety for some commentators, notably American ones (Donald Trump included) who fear rising Chinese (and Russian) influence at America's expense and will be closely watching China's actions in this sphere.

Meanwhile, Huawei 华为 - the largest telecommunications equipment company in the world since 2012 - has taken a leading role in setting technical standards for next generation mobile 5G communications (crucial for the realisation of the 'Internet of things' and driverless cars). Chinese firms increasingly have the technical capacity, skills, and knowledge to justify their standards being adopted as international ones. One way they achieve this is by buying up foreign high-tech firms, though sometimes governments (US and Australian, for example) block the sale. While such rejections spark angry complaints in Beijing, there is, of course, no reciprocity: the Party-state does not allow foreign companies to invest in industries they deem related to China's national interest.

\section{An Extraterritorial Policeman}

In November, Meng Hongwei 孟宏 伟, a Vice-Minister of Public Security, was elected head of Interpol. He is one of an increasing number of Chinese officials who are also influential players in international institutions. The case of Meng and Interpol is remarkable as it represents a hitherto hard-to-imagine degree of influence over a law and order body that prosecutes terrorism, transnational crime, and cy-



Head of Interpol, Meng Hongwei

Source: $23 \mathrm{H}$ News, Flickr bercrime. This is particularly significant in light of accusations of Chinese state-linked hacking into US websites (accusations China vociferously de- 
nies), the state-organised kidnapping abroad of Hong Kong publishers and booksellers and other dissidents, and the political nature of law and criminal justice in China itself (see Chapter 2 'Control by Law', pp.40-57). Less than three weeks after Meng's election, on 29 November, the sixty-yearold democracy and human rights advocate Peng Ming 彭明 died in a Hubei prison. Peng, a Christian, had been granted refugee status in the US but, in 2004, was kidnapped from Burma, having been lured there on the pretext of meeting his parents. He had been in prison in China ever since. Meng's appointment reflects an increasing willingness by the international community to turn a blind eye to such abuses when convenient - a huge win for China's goal of asserting its values and norms in the global sphere.

\section{The CCP and the Chinese Diaspora}

Peng Ming's death is a reminder of one of the most dramatic expressions of the Party-state's desire for increased control and influence over the Chinese diaspora. His abduction, and the 2015 kidnappings of the five Hong Kong booksellers (see Chapter 7 'Policing the Borders: Hong Kong Conundrums, pp.236-253) reflect an increased confidence that the Party-state can get away with breaking international laws (in this case, against 'enforced disappearance') when it suits them; it also reflects a rising intolerance of dissident expression abroad. This also mirrors the Party-state's belief that it has a right to treat any ethnic Chinese as subjects of the PRC even if they have since taken on foreign citizenship.

In August, China reported that Foxhunt 2016 - the overseas arm of the anti-corruption drive (see the China Story Yearbook 2014: Shared Destiny, Information Window 'Naked Officials', pp.236-237) — had successfully returned 409 suspects to China for further investigation. In Australia, Zhou Shiqin 周世勤 and Tang Dongmei 唐冬梅 both returned home 'voluntarily' after their cases were publicised across Chinese state media. In Zhou's case, this involved the publication of her photo and an Interpol notice. Authorities also put intense pressure on her sister to persuade Zhou to turn herself in. 'A fugitive is like a kite, the body is overseas but the 


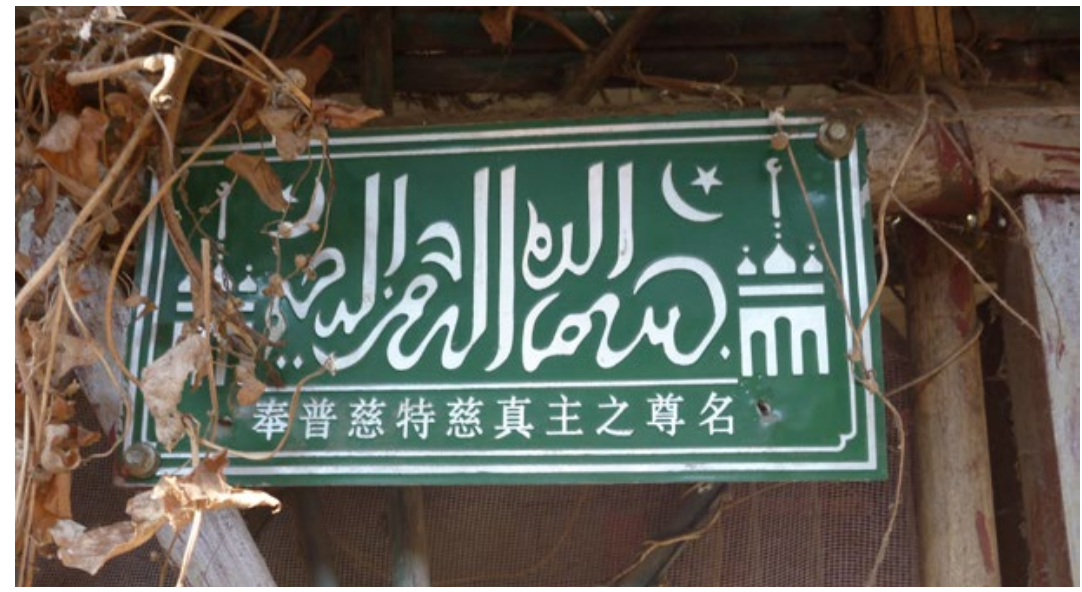

\section{Islam in Yunnan}

Photo: Gerry Groot

thread is inside China - through family and friends, [we] can always find them (sic)', a leader of Shanghai police's Economic Crimes Unit declared in 2014. ${ }^{8}$ Critics are concerned that some of Foxhunt's activities, such as sending undercover agents abroad to pursue investigations and to pressure suspects, their families and friends, fall into a grey area that may well violate other nations' laws.

There are now an estimated fifty million Chinese people living outside of China according to The Bluebook of Overseas Chinese, including members of established multi-generational, ethnically Han communities as well as newly arrived students, and business migrants, and small numbers of Uyghurs and Tibetans (although the latter are generally not counted as 'huaqiao'). As I wrote in last year's Yearbook (see the China Story Yearbook 2015: Pollution, Forum 'The Expansion of the United Front Under Xi Jinping', pp.167-177), the Party-state has sought to maintain and reinforce the loyalties of both new migrants and long-established overseas Chinese in numerous ways, including United Front Work.

The Party-state has also extended its influence deep into Chinese-language media abroad through numerous means including training journalists, supplying content, purchasing advertising, and offering official endorsements. Reuters reported in late 2015 that China Radio International controls a significant portion of Chinese-language radio around the world (specifically in the US, Australia, and Europe), via holding companies in a way that gets around any legislation (such as exists in the US) against foreign powers holding radio licences. ${ }^{9}$ 
Australia provides a good example of how this increasing influence can manifest. Australia's national public broadcaster, the Australian Broadcasting Corporation (ABC) struck a deal in 2014 to shut down its own uncensored Mandarin-language news service in order to send content into China via AustraliaPlus.cn. The ABC's own Media Watch program was among those that asked tough questions about the deal, noting that among the stories dropped from the feed to China were those related to the

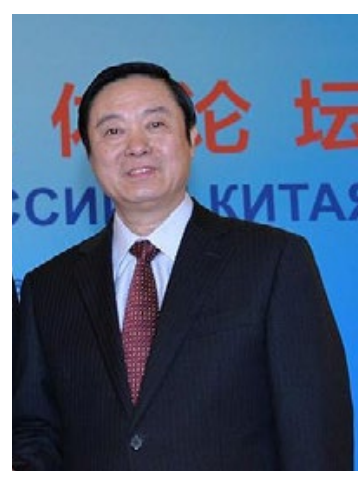

Liu Qibao

Photo: en.kremlin.ru Panama Papers (an early 2016 leak of 11.5 million documents, mainly on tax evasion), Chinese cyber-attacks on the $\mathrm{Bu}$ reau of Meteorology, and the exhibition in Australia of work by Ai Weiwei 艾未末. A belated ABC decision to return to independent news was only made in November 2016.

Meanwhile, the visit of propaganda chief Liu Qibao 刘奇葆 to Australia in May 2016 resulted in a number of under-reported agreements between Chinese media entities and Australian companies. One outcome was the appearance in Fairfax newspapers of China Daily inserts. China Daily itself was clear about the importance of this deal: 'Fairfax Media owns three important Australian daily newspapers and nine others in New Zealand, through which China Daily's influence will be spread to cover the two most important countries in Oceania'. The title of the article was also notable: 'Media exchanges to help soft power sow understanding'. ${ }^{10}$

Chinese print media are especially vulnerable to manipulation and control, thanks in part to the fact that the overseas Chinese press is almost totally reliant on advertising. Yan Xia, editor of the Sydney paper Vision Times reported that the Chinese Ministry of State Security 国家安全部 pressured one of its best advertisers, a migration agent in Beijing, to withdraw from his paper for its perceived hostility to the Party-state's agenda. ${ }^{11}$ Chinese consular officials regularly make their views known to local media. Chinese migrant communities reliant on local Chinese media for their 
news and information may not be entirely aware of the resulting bias, as a 2016 review by Wanning Sun of Chinese-language media in Australia revealed. ${ }^{12}$

On 23 July, in Melbourne, some 3,000 Chi-

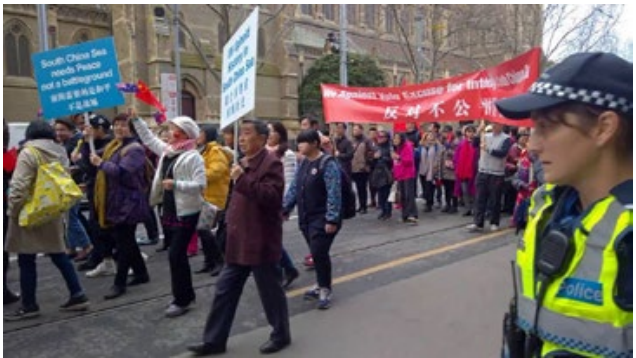

July 2016: Chinese protestors in Melbourne Source: YouTube nese from 169 community associations and fifteen Chinese-language media outlets took part in a large-scale protest at The Hague Tribunal's ruling in favour of the Philippines against China's claims to maritime boundaries in the South China Seas. (See the China Story Yearbook 2015: Pollution, Chapter 6 'Belt Tightening', pp.214-239.) The organiser, a 'Mr Li', said it was to protest American involvement behind the decision and to urge Australia not to follow the US example..$^{13}$

The participation of so many Chinese community organisations and media in the protest strongly suggests active United Front Work behind it. As I wrote in last year's Yearbook, since 2014 the CCP has stepped up such work aimed at the Chinese diaspora, including citizens studying abroad. On 4 December 2016, the CCP Central Committee Office 中国共产党中央委 员会 formally restated the importance of working with overseas Chinese, cultivating their patriotism, guiding their political consciousness, using them to support China's diplomacy, and encouraging their entry into the mainstream of the societies they live in, where they could presumably influence the broader community in China's favour. ${ }^{14}$

The kind of connections fostered by such a policy cost one prominent Australian politician dearly in 2016. Senator Sam Dastyari had broken ranks with both his own (Labor) party and government policy on the South China Sea disputes, taking China's side. Trouble arose when Dastyari revealed that he had asked a company run by Chinese businessman 


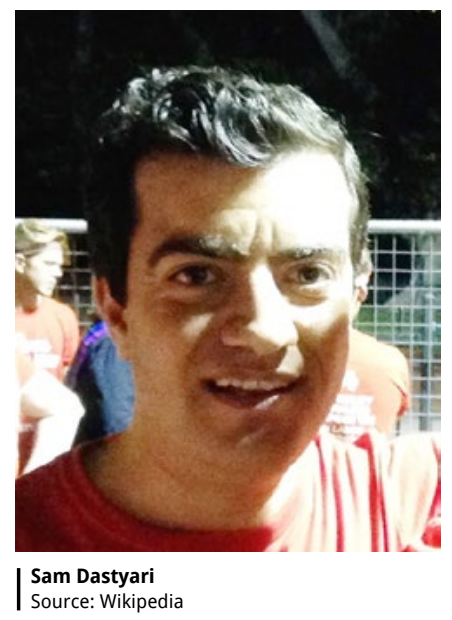

(and Chinese People's Political Consultative Conference delegate) Zhu Minshen 祝敏申 to cover staff travel expenses above the amount of his parliamentary entitlement: AU\$1,640. Then it emerged that the property developer and founder of the Australia Council for the Promotion of Peaceful Reunification of China, Huang Xiangmo 黄向墨, had helped Dastyari out a few years earlier with substantial legal fees. It turned out that Dastyari had visited China twice as the guest of the Chinese People's Institute of Foreign Affairs 中国人民外交学会 and the International Department of the Communist Party 中国共产党中央对外联络部.

In this case, China's bid for influence went wrong. The scandal fuelled suspicion over Chinese influence in Australian politics and cost a hitherto popular politician more than his reputation: Dastyari resigned his position as manager of opposition business in the Senate and moved to the backbench.

The Dastyari affair highlighted the degree to which Chinese donors were contributing to Australian politicians more generally. An ABC investigation found Chinese-linked businesses to be the largest donors to both the Labor and Liberal parties, donating more than AU\$5.5 million between 2013 and 2015. Many of the donors had strong United Front connections. The scandal also drew attention to China's growing influence in Australian universities. Huang Xiangmo is a major player in this regard, having donated AU\$1.8 million to the University of Technology Sydney towards the establishment of its Australia-China Relations Institute (ACRI), of which he was, until recently, the chair. He has also pledged AU\$3.5 million to the University of Western Sydney to set up an Australia-China Institute for Arts and Culture. Huang, using his title of ACRI chairman, subsequently 


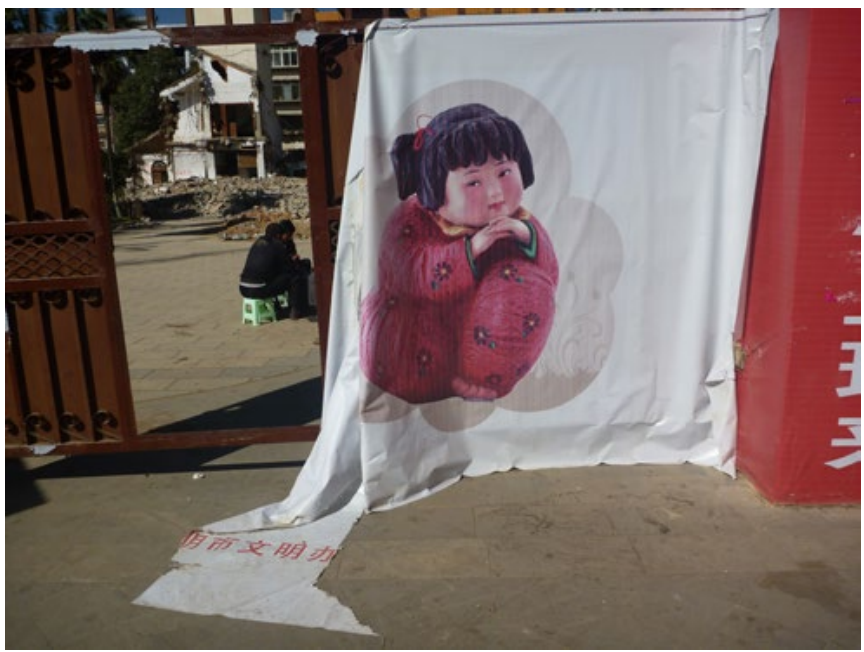

The China Dream in Yunnan

Photo: Gerry Groot

wrote in the Global Times that Australian media was 'groundless and racist in its accusations [that] Chinese-linked payments could skew Australia's democracy', arguing that Chinese donors had a legitimate role to play in Australian politics. ${ }^{15} \mathrm{He}$ resigned as chair in September, suggesting that he had been 'unfairly' scrutinised for his donations, that the Australian media had been 'biased' in its coverage, and that Australia was in the grip of both racism and a kind of 'McCarthyism'.

ACRI, which officially bases its work 'on a positive and optimistic view of Australia-China relations', was left having to defend its intellectual independence and integrity. Its director, former state premier and later foreign affairs minister Bob Carr, similarly decried critics as 'Cold War warriors', who were themselves unduly influenced by Washington. Yet as Anne-Marie Brady wrote in 2015, influencing foreign think tanks through donations and so on to adopt a more positive view of China is precisely one of the many ways Beijing has sought to shift global perceptions of itself. ${ }^{16}$ 
Chinese students are also becoming more active in student and university politics. In one incident on The Australian National University campus, a student who identified himself as president of the Chinese Student and Scholars Association demanded that the university pharmacy discontinue its distribution of Falun Gong's Epoch Times, which had been stocked there since November 2015. The surveillance of Chinese students by such 'patriotic' organisations has long been a concern. In October, $\mathrm{ABC}$ radio's Background Briefing brought to light some disturbing examples of harassment of students holding dissident opinions and of ties between consular and student organisations. ${ }^{17}$

\section{Conclusion}

The CCP Party-state today is extending its global influence in multiple and often subtle ways, at the same time as it is actively and vociferously reducing any ability of foreign nations to do the same in China. At home, it is even extending its demands to shape curricula in international schools and stepping up ideological education in schools and universities to prevent what it sees as Western ideological infiltration. Yet there is a real risk that growing awareness of China's increasing reach into other nations via combinations of state, private, and ostensibly civil society organisations will fuel perceptions of both interference in others' internal affairs and result in doubts about the loyalty to their adopted countries of ethnic Chinese around the world. Such fears may well spark or inflame racist sentiments and are especially dangerous in countries such as Malaysia and Indonesia where anti-Chinese feelings are easily stoked. The CCP's attempts to both claim all overseas Chinese as China's own as well as use them to influence local politics is a perilous game. It not only endangers all overseas Chinese by impugning their loyalties, it is also an implicit threat to the political integrity of immigrant-based nations including Australia, Canada, the US, and others, which are ill equipped to deal with such issues. 
This text is taken from China Story Yearbook 2016: Control, edited by Jane Golley, Linda Jaivin and Luigi Tomba, published 2017 by ANU Press, The Australian National University, Canberra, Australia. 